\title{
Motyw "drogi" jako element potwierdzający hipotezę Łukaszowego autorstwa Listu do Hebrajczyków
}

\section{The motif of "the road" as an element confirming the hypothesis of Luke's authorship of the Letter to the Hebrews}

Słowa klucze: List do Hebrajczyków; autorstwo; droga; święty Łukasz; Opus Lucanum; Jerozolima; Miejsce Święte.

Key words: A letter to Hebrews; authorship; the road; saint Luke; Opus Lucanum; Jerusalem; the Sanctuary.

Streszczenie. Artykuł porusza kwestię autorstwa Listu do Hebrajczyków. Rozpoczynając od analizy różnych próby wyjaśniania na przestrzeni wieków tego zagadnienia, pokazuje złożoność problemu. Jednym z domniemanych autorów Listu jest św. Łukasz, twórca Ewangelii i Dziejów Apostolskich. Artykuł skupia się na znalezieniu dowodów jedności teologicznej i literackiej wspomnianych ksiąg z Listem do Hebrajczyków. Jednym z ważnych argumentów przemawiającym za Łukaszowym autorstwem tego dzieła, jest motyw „drogi”, który będąc podstawą struktury Ewangelii i Dziejów Apostolskich, ukierunkowuje nas także na List do Hebrajczyków.

\begin{abstract}
The article raises the question of the authorship of the Letter to the Hebrews. Starting from the analysis of various attempts to explain this issue over the centuries, it shows the complexity of the problem. One of the alleged authors of the Letter is St. Luke, the author of the Gospel and the Acts of the Apostles. The article focuses on finding evidence of the theological and literary unity between those books and the Letter of the Hebrews. One of the important arguments in favor of Luke's authorship of this work is the theme of "the road", which - being the basis of the structure of the Gospel and the Acts of the Apostles - also directs us towards the Letter to the Hebrews.
\end{abstract}


utorstwo Listu do Hebrajczyków należy do jednych z największych zaga-
dek współczesnych badań biblijnych. Na przestrzeni wieków powstał szereg mniej lub bardziej wiarygodnych hipotez, które próbowały dowodzić tego, kto stoi za tym jednym z ważniejszych dzieł Nowego Testamentu. Kościół na Wschodzie od początku za autora Hbr zaczął uważać św. Pawła, co pomogło dostać się tej księdze - jednak nie bez problemu - do kanonu Pisma Świętego. Warto w tym miejscu zacytować Klemensa Aleksandryjskiego, który taką tradycję uzasadnia słowami: „Paweł, dzierżąc posłannictwo do pogan, w swej skromności nie wypisuje sam dla siebie tytułu apostoła Żydów, z jednej strony z uszanowania dla Pana, a potem dlatego, że pisał do Żydów ponad swój obowiązek, bo był pogan heroldem i apostołem"1. Pogląd ten funkcjonował przez wiele lat w katolickiej egzegezie, był nawet nakazany dekretem Komisji Biblijnej z 1914 r., który jasno potwierdzał Pawłowe autorstwo Listu². Takie twierdzenie zostało jednak odrzucone już przez Orygenesa ${ }^{3} \mathrm{w}$ pierwszej połowie III w. Wśród innych domniemanych autorów wymieniani wówczas byli m.in.: Klemens Rzymski ${ }^{4}$, Juda ${ }^{5}$, Barnaba (m.in. przez Tertuliana) ${ }^{6}$, a nawet Apollos (teza powstała w okresie Reformacji) ${ }^{7}$.

\section{Hipoteza Łukaszowego autorstwa Listu do Hebrajczyków}

Oprócz wspomnianych wyżej wielkich postaci czasów Apostolskich, wśród domniemanych autorów Listu do Hebrajczyków wymieniany jest także święty Łukasz. Klemens Aleksandryjski, który za pewnik uznawał Pawłowe autorstwo, w Ewangeliście widział tłumacza jego listu na język grecki ${ }^{8}$. Również Orygenes zauważył, że greka użyta w Hbr jakością daleko przewyższa inne teksty św. Pawła ${ }^{9}$, a tym samym w gronie potencjalnych autorów bez wątpienia znajdu-

1 Cyt. za: Euzebiusz z Cezarei, Historia Kościelna, s. 268.

2 Por. J. Frankowski, Problem autorstwa Listu, s. 3.

3 Por. A. Paciorek, Pawet Apostot - pisma, s. 74.

4 Pismo święte Nowego Testamentu, s. 2621.

5 Pismo święte Starego i Nowego Testamentu, s. 1563.

6 Za Barnabą jako autorem listu opowiada się ks. Antoni Tronina, który w swojej książce Do Hebrajczyków, jednoznacznie owego ucznia św. Pawła przedstawia jako autora Hbr.

7 Por. A. Tronina, Do Hebrajczyków, s. 8-9.

8 Por. ibidem, s. 7; E. Dąbrowski, Studia Biblijne, s. 203.

9 Por. Euzebiusz z Cezarei, Historia Kościelna, VI, 25, cyt. za: A. Tronina, Do Hebrajczyków, s. 8 . 
je się św. Łukasz, który umiejętności w sztuce pisania udowodnił w Ewangelii i Dziejach Apostolskich. W podobnym duchu wyraża się m.in. ks. Eugeniusz Dąbrowski, który napisał: „Język grecki listu nie da się porównać z żadną inną księgą Nowego Testamentu, może tylko z prologiem do Ewangelii Łukasza"10. Co prawda, Łukaszowe autorstwo Listu jest cały czas tylko hipotezą, to jednak nie ma również jednoznacznych dowodów przeciw takiemu myśleniu. Podobnego zdania jest ks. Tomasz Jelonek, który wskazuje na szereg cech wspólnych występujących pomiędzy Łk i Dz a $\mathrm{Hbr}^{11}$.

List do Hebrajczyków, mimo że rozwija własną, oryginalną teologię, ma wiele punktów stycznych z innymi księgami Nowego Testamentu i zdecydowanie pasuje do całości Pisma świętego ${ }^{12}$. Ks. Jelonek na podstawie fragmentu Hbr 2,3b, stara się udowodnić jego ścisły związek z Ewangelią Łukasza i Dziejami Apostolskimi ${ }^{13}$. Werset: Było ono (zbawienie) głoszone na poczatku przez Pana, a umocnione w nas przez tych, którzy je styszeli, jest koronnym argumentem stosowanym przez przeciwników Pawłowego autorstwa tej księgi, gdyż Apostoł Narodów nigdy nie określiłby siebie mianem „chrześcijanina drugiej generacji”" Ten fragment poza tym, że wskazuje na to kim autor nie jest, sam w sobie ( $\mathrm{w}$ raz z następującym po nim Hbr 2,4) stanowi zwięzłe streszczenie Dzieła Łukaszowego (Łk-Dz). Jest niejako pośrednim dowodem, że autorem tej zagadkowej księgi mógłby być św. Łukasz. W Hbr 2,3 czytamy, że mamy troszczyć się o cenne

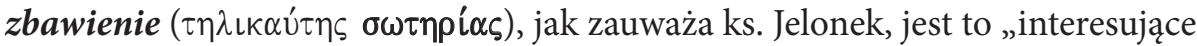
nas streszczenie dziejów głoszenia, umacniania i poświadczania zbawienia"15.

Rzeczownik $\sigma \omega \tau \eta \rho i \alpha$ występuje 27 razy w pismach Nowego Testamentu z czego aż siedemnastokrotnie w Dziele Łukaszowym ${ }^{16}$ (Łk 1,69; 1,71; 1,77; 19,9; Dz 4,12; 7,25; 13,26; 13,47; 16,17; 27,34; Hbr 1,14; 2,3; 2,10; 5,9; $6,9 ; 9,28 ; 11,7)$, co daje nam uzasadnione podstawy do analizy tego terminu jako jednego $z$ kluczowych $w$ terminologii autora Łk-Dz-Hbr ${ }^{17}$. W Liście

10 E. Dąbrowski, Studia biblijne, s. 201.

11 Por. T. Jelonek, Streszczenie dzieł Łukaszowych, s. 143-151.

12 Por. ibidem, s. 143.

13 Por. ibidem.

14 Por. J. Frankowski, Problem autorstwa Listu, s. 15.

15 T. Jelonek, Streszczenie dzieł Łukaszowych, s. 144.

16 Jako Dzieło Łukaszowe w tym miejscu uznaję Ewangelię wg św. Łukasza, Dzieje Apostolskie i List do Hebrajczyków. Wspomniane słowo występuje ponadto w: Mk 16,8; 2 Kor 1,6; 6,2; Ef 1,13; Flp 1,28; 1 Tes 5,8.9; 2 Tm 2,10; 1 P 1,10 i Jud 1,3.

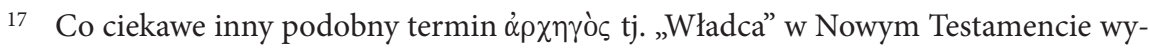
stępuje wyłącznie w Dziejach i Liście do Hebrajczyków (Dz 3,15; 5,21 i Hbr 2,10; 12,2), por. J. Gnilka, Teologia Nowego Testamentu, s. 265. 
do Hebrajczyków Jezus nazwany jest przewodnikiem zbawienia (Hbr 2,10), sprawca zbawienia wiecznego dla wszystkich, którzy Go stuchaja (Hbr 5,9) i Tym, który ukaże się ponownie dla zbawienia tych, którzy Go oczekuja (Hbr 9,28). Ponadto autor Hbr wspomina o tych, którzy mają odziedziczyć zbawienie (Hbr 1,14), którzy są bliscy zbawienia (Hbr 6,9) i którzy mają troszczyć się o tak cenne zbawienie (Hbr 2,3). Dodatkowo w opisie wiary przodków wspomina o Noem który zbudował arkę, aby ocalić (zbawić - $\sigma \omega \tau \eta \rho i ́ \alpha \nu)$ swoja rodzinę (Hbr 11,7). Spośród synoptyków jedynie Łukasz nazywa Jezusa Zbawicielem - $\sigma \omega \tau \eta \dot{\rho}$. Tego określenia używa trzykrotnie zapowiadając nadchodzące zbawienie w „Pieśni Zachariasza” (Łk 1,69.71.77), w opisie spotkania Zacheusza, którego domu udziałem stało się Boże zbawienie (Łk 19,9), oraz w słowach Jezusa: Syn Człowieczy przyszedł odszukać i zbawić to, co zginęło

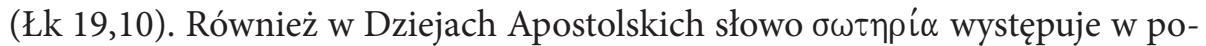
dobnym kontekście ${ }^{18}$, gdzie mowa jest o Mojżeszu - typie Chrystusa ${ }^{19}$, którego celem było zbawienie ( $\mathrm{Dz} 7,25)$ i o Jezusie w którym jest jedyne zbawienie (Dz 4,12). Święty Łukasz pisze również o działalności św. Pawła, którego celem jest głoszenie zbawienia (Dz 13,26.47; 16,17). Ks. Tomasz Jelonek dowodzi, że zdanie z Hbr 2,3b-4 jest streszczeniem dwóch poprzednich dzieł Łukasza i tak słowa: było ono (zbawienie) na poczatku głoszone przez Pana odnoszą się do Ewangelii według św. Łukasza, a zdania: a umocnione przez tych, którzy je słyszeli oraz Bóg zaś uwierzytelnit je znakami, cudami i różnorakimi przejawami mocy i Ducha Świętego według swej woli są streszczeniem dwóch głównych nurtów Dziejów Apostolskich ${ }^{20}$. Autor Listu do Hebrajczyków używając perfekcyjnej greki dokonuje syntezy dwóch dzieł Łukaszowych, a - jak słusznie zauważa autor artykułu - „kto może najlepiej znać istotne nurty Trzeciej Ewangelii i Dziejów Apostolskich, jeśli nie sam ich autor?"21 Jest to jeden z podstawowych dowodów na Łukaszowe autorstwo tego najbardziej zagadkowego dzieła Nowego Testamentu.

18 Tylko raz słowo $\sigma \omega \tau \eta \rho i ́ \alpha$ występuje w innym znaczeniu - jako ocalenie pasażerów podczas burzy na morzu w Dz 27,34.

19 Ks. Tomasz Jelonek odwołuje się do dwóch swoich dzieł poświęconych temu zagadnieniu: T. Jelonek, Typologia Mojżesz - Chrystus, s. 111-124, oraz T. Jelonek, Postać Mojżesza, s. 107-110. Cyt. za: T. Jelonek, Streszczenie dzieł Łukaszowych, s. 145, przypis 6.

20 Por. ibidem, s. 150.

21 Ibidem. 


\section{2. Łukaszowy motyw "drogi"}

Spośród wielu dowodów mówiących o jedności Dwudzieła Łukaszowego jeden nabiera szczególnego znaczenia, gdyż jako podstawa teologicznej i literackiej jedności Ewangelii i Dziejów Apostolskich, ukierunkowuje nas także na trzecią księgę, tj. List do Hebrajczyków. Motyw drogi ${ }^{22}$, który występuje we wspomnianych księgach, łączy je w pewną strukturę, którą dużo łatwiej zrozumieć, gdy odczytuje się ją w kontekście całego Opus Lucanum (do którego włączam także List do Hebrajczyków). Droga, która prowadzi Jezusa do Jerozolimy (Łk), a następnie uczniów począwszy od niej, aż po krańce świata (tj. Rzym - Dz), ma swoją kontynuację w pielgrzymce ku Nowemu Miastu, Niebieskiemu Jeruzalem (Hbr).

Gdy przyjrzymy się teologicznej strukturze dzieła świętego Łukasza, zobaczymy, że próbuje on, posługując się znaną mu tradycją, przeprowadzić czytelnika przez wyraźnie zaplanowany schemat. Wszystko ogniskuje się wokół Świętego Miasta, jakkolwiek byśmy je rozumieli. W Ewangelii Łukasza jest to niewątpliwie Jerozolima, gdyż cała struktura księgi, nakierowana jest na Jeruzalem. Motyw drogi - obecny co prawda w będącej tekstem źródłowym Ewangelii Marka (por. Mk 10), lecz niezwykle rozbudowany - jest fundamentem całej struktury dzieła. Łukasz celowo pominął mniej znaczące lub zmodyfikował te istotne elementy tradycji, aby włączyć je w stworzony przez siebie obraz nieustannej pielgrzymki Jezusa do Jerozolimy. Żadna z głównych części Ewangelii, to jest: Ewangelia Dzieciństwa (Łk 1,5-2,53), przepowiadanie Jana Chrzciciela (Łk 3,1-20), „sekcja podróży” (Łk 9,51-19,27) i opis chrystofanii popaschalnej (Łk 24,13-35), nie jest pozbawiona tego motywu. Jest on szkieletem, na którym Łukasz buduje swoją relację o wydarzeń zbawczych. W motywie drogi w Dziejach Apostolskich akcent położony jest na inną metropolię - Rzym, nowe Święte Miasto chrześcijan, które przejmuje dotychczasową rolę Jerozolimy. Wraz z przyjęciem wiary przez pogan, to stolica Cesarstwa - kraniec ziemi (por. Dz 1,8) staje się nowym centrum, tym ku któremu zmierza cała teologiczna struktura Dziejów Apostolskich. Jezus w Ewangelii mówił: Oto wyrzucam złe duchy i dokonuję uzdrowień dziś i jutro, a trzeciego dnia będę u kresu. Jednak dziś, jutro i pojutrze muszę być $w$ drodze, bo rzecz niemożliwa, żeby prorok zginat poza Jeruzalem (Łk 13,32-33), natomiast w Dziejach Apostolskich Zmartwychwstały Pan powiedział do Pawła: Odwagi! Trzeba bowiem, żebyś i w Rzymie zaświadczył o Mnie, tak jak dawałeś o Mnie świadectwo w Jeruzalem (Dz 23,11).

22 Na temat motywu drogi w Ewangelii wg św. Łukasza i w Dziejach Apostolskich pisze Dariusz Kotecki w „Droga” jako element, s. 55-76. 
Jak widać, w słowach Jezusa Łukasz przekazał zarys budowy obu ksiąg. Ponownie temat Świętego Miasta powraca w Liście do Hebrajczyków, a jego mianem określone jest niebieskie Jeruzalem (Hbr 12,22). Jezus, po Wniebowstąpieniu otwiera nową drogę, tę, która prowadzi do Miejsca Świętego, nowej góry Syjon, do miasta Boga żywego (Hbr 12,22).

W każdej z omawianych ksiąg można spotkać się z motywem wypełniania się, kontynuacją drogi zapoczątkowanej w Starym Testamencie. Gdy weźmiemy pod uwagę samą tylko „Biblię Jerozolimską”, zobaczymy, że jej redaktorzy w odpowiednich przypisach dopatrzyli się olbrzymiej ilości inspiracji księgami Starego Prawa. Łukasz w samej tylko Ewangelii ok. 194 razy nawiązuje do ST, w Dziejach Apostolskich ok. 174, a w Liście do Hebrajczyków ok. 154-krotnie $^{23}$. Charakter wypełnienia ma też motyw wkraczania do Miejsca Świętego, w Ewangelii jest to wędrówka Mesjasza do Jerozolimy, gdyż niemożliwe jest by prorok zginał poza Jeruzalem (Łk 13,33), a w Hbr nawiązanie do starotestamentalnej liturgii, w której w rolę Arcykapłana wciela się Zmartwychwstały Pan (Hbr 9,11, por. Kpł 16).

W każdej z tych ksiąg, czytamy o nieustannej pielgrzymce do jakiegoś miasta, o ciągłym ruchu i wkraczaniu. Autor używa wielokrotnie tych samych słów mówiących o podróży, o byciu „w drodze”, na przykład:

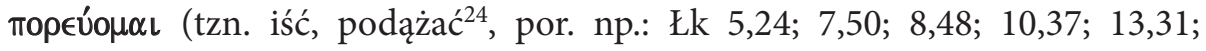
$17,19$ i Dz 8,$26 ; 9,15 ; 10,20 ; 22,10 ; 22,21 ; 24,25)$,

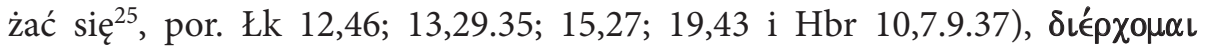
(tzn. przechodzić ${ }^{26}$, por. Łk 2,15.35; 4,30; 5,15; 8,22; 9,6; 11,24; 17,11; $19,1.4, \mathrm{Dz} \quad 8,4.40 ; 9,32.38 ; 11,19.22 ; 12,10 ; 13,6.14 ; 14,24 ; 15,3.41 ; 16,6$;

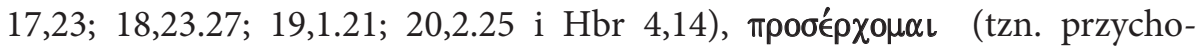
dzić, przystępować ${ }^{27}$, por. Łk 7,$14 ; 8,24.44 ; 9,12.42 ; 10,34 ; 13,31 ; 20,27$; $23,36.52$, Dz 7,$31 ; 8,29 ; 9,1 ; 10,28 ; 12,13 ; 18,2 ; 22,26.27 ; 23,14 ; 28,9$ i Hbr 4,$16 ; 7,25 ; 10,1.22 ; 11,6 ; 12,18.22)$. Wyrażenia oznaczające ruchu znajdują się we wszystkich częściach ksiąg, zarówno w pierwszych, jaki w ostatnich rozdziałach, co niewątpliwie jest dowodem na konsekwentne budowanie literackiej struktury mającej na celu podkreślenie znaczenia „drogi” w całej koncepcji autora. Nie można oczywiście pominąć kluczowego słowa, którym posługuje się redaktor „drogi Pana”28, tj. greckiego óós, które obecne jest w każdej z tych

Por. Biblia Jerozolimska, s. 1425-1466, 1515-1559, 1687-1699.

24 Por. R. Popowski, Wielki słownik grecko-polski, s. 515.

25 Por. ibidem, s. 260.

26 Por. ibidem, s. 137.

27 Por. ibidem, s. 529.

28 Por. D. Kotecki, „Droga” jako element, s. 62.
} 
trzech ksiąg. Użycie tego charakterystycznego wyrazu dwudziestokrotnie w Ewangelii Łukasza, tyleż samo w Dziejach Apostolskich i trzykrotnie w Liście do Hebrajczyków, pozwala sądzić, że jest to słowo wykorzystane przez autora Opus Lucanum w sposób świadomy i celowy. Samo słowo przechodzi też pewnego rodzaju ewolucję, w pierwszej księdze przyjmuje formę wyrażenia podkreślającego pielgrzymi charakter nauczania Jezusa (np. Łk 2,44; 9,57; 18,35; 19,36), ale także oznacza pewną decyzję, wybór konkretnej drogi, drogi Pana (por. Łk 1,79; 3,4; 20,21). W Dziejach spotykamy óđós jako określenie mówiące o podróży Apostołów (np. Dz 1,12; 8,26.36.39; 26,13), ale także, co jest szczególnie ważne, jako określenie nowopowstałej wspólnoty chrześcijan (por. Dz $9,2 ; 19,9 ; 19,23 ; 22,4 ; 24,14 ; 24,22)$. W Liście do Hebrajczyków autor ponownie nawiązuje do rozumienia óoós jako drogi Pana, tej, która prowadzi do Miejsca Świętego (por. Hbr 3,10; 9,8; 10,20), do Nowego Jeruzalem.

\section{Motyw „drogi" w Liście do Hebrajczyków}

Słowo óó́s poza Ewangeliami i Dziejami Apostolskimi występuje w Nowym Testamencie jeszcze 15 razy z czego tylko czterokrotnie w zbliżonym do omawianego motywu kontekście (1 Kor 12,31; Jk 5,20; 2 P 2,2.21), pozostałe to wyrazy czysto techniczne (Jk 2,25; 1 Tes 3,11, Ap 16,12), cytaty ze Starego Testamentu (Rz 3,16.17; 11,33; Ap 15,3) oraz określenia związane z drogą innych postaci biblijnych (1 Kor 4,17; 2 P 2,15; Jk 1,8; Jud 11). Święty Paweł w Pierwszym Liście do Koryntian wspomina o drodze: Lecz wy starajcie się o większe dary: a ja wam wskażę drogę (óò̀) jeszcze doskonalsza (1 Kor 12,31). W całym Corpus Paulinum tylko we wprowadzeniu do „Hymnu o miłości” św. Paweł mówi o „drodze doskonalszej”. Mamy w tym wypadku jednak do czynienia raczej z określeniem mówiącym o przyjętym stylu życia, tak jak miał znaczenie ten termin w ówczesnym języku greckim ${ }^{29}$, a nie o jakimś motywie drogi. W Liście św. Jakuba natomiast czytamy: Bracia moi, jeśliby ktokolwiek $z$ was zszedł $z$ drogi prawdy, a drugi go nawrócit, niech wie, że kto nawrócił grzesznika z jego błędnej drogi (ódoû), wybawi duszę jego od śmierci i zakryje liczne grzechy (Jk 5,19-20). Słowo óó́ $\mathrm{w}$ tym wypadku jest nawiązaniem do poprzedniego wersetu i, jako kontynuacja użytego zdania warunkowego, oznacza zaprzecze-

29 Należałoby wspomnieć m.in. Jamblicha, który mówi o „drogach i metodach wychowania”, Heraklita z Efezu piszącego: „Najkrótszą drogą do sławy jest okazanie się szlachetnym” oraz Demokryta z Aberty i jego słowa: „życie bez przyjemności jest jak długa droga bez przystanku”. Wszystkie cytaty za M. Rosik, Pierwszy List do Koryntian, s. 423. 
nie Prawdy ${ }^{30}$. Sama zaś „droga prawdy”, o której słyszymy w tłumaczeniu Biblii Tysiąclecia, nie jest przekładem greckiego óoós, lecz pochodzi od słów: $\pi \lambda \alpha \nu \eta \theta \hat{n}$

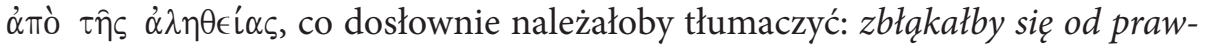
$d y^{31}$. Autor Listu św. Jakuba nie używa zatem charakterystycznego dla terminologii Łukasza terminu „droga” na oznaczenie drogi Jezusa lub na oznaczenie wspólnoty pierwotnego Kościoła. W podobnym kontekście słowo ódós użyte jest dwukrotnie w Drugim List św. Piotra: A wielu pójdzie za ich rozpustą, przez

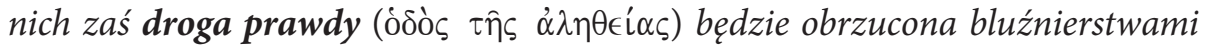
(2 P 2,2) i Lepiej byłoby im nie znać drogi sprawiedliwości (

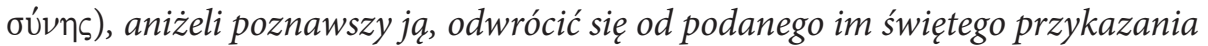
(2 P 2,21).

W żadnej z wymienionych ksiąg Nowego Testamentu słowo ódós nie nabiera takiego charakteru jak w Liście do Hebrajczyków, co postaram się udowodnić w dalszej części tego artykułu. Jedynie on zawiera nie tylko samo wyrażenie użyte w odpowiednim znaczeniu, ale kontynuacje zapoczątkowanej myśli z Dwudzieła Łukaszowego. Do takiego wniosku pośrednio można też dojść czytając „Słownik teologii biblijnej”, w którym autorzy przytaczając Ewangelię Łukasza piszą, że Jezus jest Tym, który wstępuje do Jerozolimy, aby tam złożyć ofiarę z samego Siebie, następnie „w Dziejach Apostolskich nowo powstałe chrześcijaństwo nazywa się «drogą» (Dz 9,2; 18,25; 24,22). I rzeczywiście chrześcijanie mieli świadomość znalezienia prawdziwej drogi, nie znanej dotychczas (Hbr 9,8)"32. Ksiądz Jelonek, próbując udowodnić tezę o Łukaszowym autor-

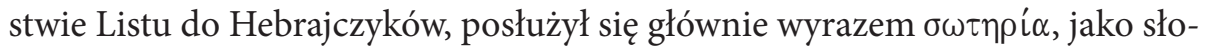
wa charakterystycznego dla autora trzeciej Ewangelii i Dziejów Apostolskich ${ }^{33}$. W tym miejscu chciałbym zwrócić uwagę, co nie zostało jak dotąd w znanej mi literaturze w sposób jednoznaczny zaznaczone, na inny charakterystyczne dla Łukasza element jego dzieł. Motyw drogi może być znaczącym dowodem potwierdzającym Łukaszowe autorstwo omawianej triady ksiąg, a tym samym stanowić ważny argument przy próbie określenia autorstwa Listu do Hebrajczyków.

Motyw „drogi” w liście do Hebrajczyków jest istotny przy próbie zrozumienia teologii jego autora. Słowo ódós występuje w tej niedużej księdze trzykrotnie: w cytowanym Psalmie 95 (Hbr 3,10), oraz dwukrotnie (Hbr 9,8; 10,2) w ewidentny sposób nawiązując do motywu drogi Ewangelii Łukasza i Dziejów

\footnotetext{
30 J. Kozyra, List świętego Jakuba, s. 302.

31 Por. R. Popowski i M. Wojciechowski, Grecko-polski Nowy Testament, s. 1098.

32 A. Darrieutort, Droga, w: X. Léon-Dufour (red.), Słownik teologii biblijnej, s. 222.

33 T. Jelonek, Streszczenie dzieł Łukaszowych, s. 144.
} 
Apostolskich. Poddam zatem analizie każdy z tych fragmentów, aby można było pełniej zrozumieć koncepcję teologiczną autora Listu do Hebrajczyków.

\subsection{Otwarcie drogi do Miejsca Świętego (Hbr 9,8)}

Autor listu do Hebrajczyków opisuje wstąpienie Jezusa do niebiańskiej świątyni. W dziewiątym rozdziale księgi umieszczone jest krótkie streszczenie historii ziemskiego przybytku Boga, którym na początku był namiot (por. Hbr 9,2 i Wj 25-26). Autor listu opisuje jego wyposażenie i podkreśla, że do miejsca „Świętego Świętych” miał dostęp tylko raz w roku arcykapłan, który zobowiązany był do składania ofiary za swoje grzechy i za grzechy ludu (por. Hbr 9,3-7). Po tym opisie nawiązującym do Starego Testamentu, znajduje się znamienne zdanie:przez to pokazuje Duch Święty, żejeszcze nie została otwarta droga (óoòv) do Miejsca Świętego ${ }^{34}$, dopóki istnieje pierwszy przybytek (Hbr 9,8). Autor księgi zauważa, że starotestamentalny kult nie jest już wystarczający, ponieważ jest tylko „ziemski”35. Dawna liturgia nie dawała zatem ludziom dostępu do Boga, ponieważ w myśl starego Prawa zostali uznani za niewystarczająco świętych ${ }^{36}$. Dopiero Chrystus, jest tym, który przez własną krew

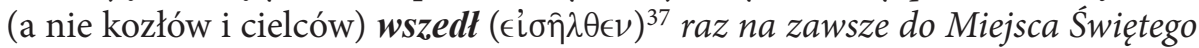
(Hbr 9,12). Jezus otwiera zamkniętą dotąd drogę, wprowadza na nią wszystkich przez złożoną raz na zawsze nieskalaną ofiarę (por. Hbr 9,14) ${ }^{38}$.

Czymże jest jednak owo Miejsce Święte do którego prowadzi nas Chrystus? Gdy czytamy tekst Ewangelii wg świętego Łukasza, rozumiemy, że Jezus szedł do Miasta Świętego - Jerozolimy, w której to - wedle wiary Izraela - znajdował się przybytek Boga, to jest Świątynia Jerozolimska. Idąc zatem do Jeruzalem, podążał ku starotestamentalnemu Miejscu Świętemu, w którym był obecny Bóg ${ }^{39}$. Jezus, co wynika zarówno z opisu ewangelijnego, jak i z Listu do Hebrajczyków, w chwili śmierci otworzył nową drogę, prowadzącą do innego przybytku, już nie ręką - to jest nie na tym świecie - uczynionego ( $\mathrm{Hbr}$

34 Termin Áyıs, co dosłownie znaczy: „święte, rzecz święta, świątynia”. Tu „Miejsce Święte”, co wynika z kontekstu, por. Hbr 9,12. Za R. Popowski, Wielki słownik grecko-polski, s. 6-7.

35 Por. J.W. Thompson, List do Hebrajczyków, s. 682.

36 Por. Pismo święte Nowego Testamentu, Częstochowa 2006, s. 2632.

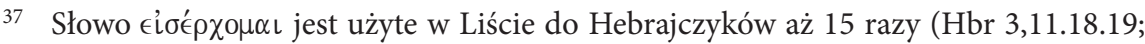
4,1.3.5.6.10.11; 6,19.20; 9,12.24.25; 10,5).

38 Podobnie wspomniane fragmenty interpretuje A. Darrieutort, Droga, s. 222.

39 Por. G.W. Buchanan, Miejsce Święte, w: P.J. Achtemeier (red.), Encyklopedia biblijna, s. 759 . 
9,11). W Dziejach Apostolskich uczniowie wyruszają z Jerozolimy, aby dotrzeć do nowej stolicy - Rzymu, który stanie się centrum chrześcijaństwa i ukaże symboliczne odejście od starotestamentalnego kultu, który zakończy się w 70 r. wraz ze zburzeniem Świątyni Jerozolimskiej. Widzimy zatem, że w każdej $\mathrm{z}$ tych ksiąg (tj. Łk i Dz) celem podróży było jakieś konkretne miasto, które zyskiwało rangę symbolu, wydaje się zatem, że nie inaczej jest w przypadku Listu do Hebrajczyków. W Hbr 4,14 czytamy, że zmartwychwstały Jezus przez wniebowstąpienie jest tym, który przeszedt $\left(\delta\llcorner\in \lambda \eta \lambda \cup \theta o ́ \tau \alpha)\right.$ przez niebiosa ${ }^{40}$. Miejscem Świętym jest zatem wedle autora niebieskie sanktuarium, w którym zasiada Bóg, a do którego Jezus wkroczył już raz na zawsze ${ }^{41}$. Chrystus, który wstąpił do nieba jest zatem nowym arcykapłanem, który złożył ofiarę najdoskonalszą - samego siebie. Do takiej interpretacji tego fragmentu nawiązuje m.in. soborowa Konstytucja: „Ziemska liturgia daje nam przedsmak uczestnictwa w liturgii niebiańskiej sprawowanej w świętym mieście, Jeruzalem, do którego pielgrzymujemy, gdzie Chrystus zasiada po prawicy Boga jako sługa świątyni i prawdziwego przybytku"42. W podobnym duchu wypowiadał się również papież Benedykt XVI w swojej książce „Jezus z Nazaretu”, w której zauważył, że główny cel „ "wchodzenia» Jezusa stanowi Jego ofiara krzyżowa, która zajmuje miejsce dawnych ofiar”, zaznacza ponadto, że „List do Hebrajczyków nazywa je wchodzeniem już nie do przybytku zbudowanego rękami ludzkimi, lecz do samego nieba, przed oblicze Boga"43.

Nowe Miejsce Święte przybrało w późniejszej teologii głównie za przyczyną Apokalipsy nazwy: „nowego Jeruzalem”, czy też „nowego Miasta Świętego” (por. Ap 3,12; 21,2), jednak również w Liście do Hebrajczyków spotykamy się z podobnym stwierdzeniem. Autor księgi pisze: Wy natomiast przyszliście do góry Syjon, do miasta Boga żywego - Jeruzalem niebieskiego, do niezliczonej liczby aniołów, na uroczyste zgromadzenie (Hbr 12,22). Jezus zatem prowadzi nas przez swoje ziemskie życie do Jerozolimy (por. Łk 9,51-19,27), aby wstępując do nieba otworzyć nam drogę do nowej stolicy - Jeruzalem niebieskiego.

\subsection{Jezus jako droga nowa i żywa (Hbr 10,20)}

Kolejnym ważnym tekstem, w którym użyto słowo óós jest pochodzący z dziesiątego rozdziału fragment: Mamy więc, bracia, pewność, iż wejdziemy

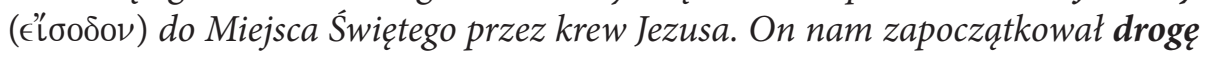

\footnotetext{
40 Por. Biblia Jerozolimska, s. 1694, przypis 9,12.

41 Por. A. Paciorek, Paweł Apostoł - pisma, s. 84.

42 Sobór Watykański II, Konstytucja o Liturgii, s. 51.

43 J. Ratzinger-Benedykt XVI, Jezus $z$ Nazaretu, s.12.
} 


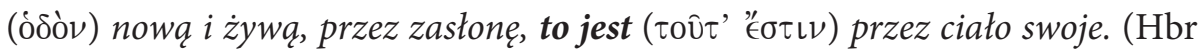
10,19-20). Ks. Antoni Tronina komentując te słowa napisał: „Zwięzłe streszczenie doktryny spowodowało niejasność pewnych wyrażeń. Charakterystyczny dla Listu do Hebrajczyków zwrot tout'estin, «to jest (jego ciało)» może odnosić się bądź do «zasłony», bądź też do całego wyrażenia wiersza 20 o nowej, życiodajnej drodze, jaką zapoczątkował Jezus"44. Dla potrzeb tego artykułu przyjmijmy założenie opierające się na drugiej tezie tego zdania. Ciało Jezusa byłoby więc przyrównane do drogi (o̊ós), a cały fragment z Hbr 10,19-20 nabrałby w tym wypadku szczególnego znaczenia.

Tekst nawiązuje do starotestamentalnej liturgii, o której mowa była już w Hbr 9,1-7, tj. do Dnia Pojednania. W dawnym kulcie to arcykapłan wchodził do Miejsca Świętego z krwią ofiar, teraz w jej miejsce pojawia się najświętsza krew Syna Bożego ${ }^{45}$. Ponadto autor listu nawiązuje do istniejącej w dawnej świątyni „zasłony” oddzielającej Miejsce Święte od Najświętszego, którą teraz zastąpiła zasłona Jego ciała (por. Hbr 10,20). Warto w tym miejscu zwrócić uwagę na inny fragment tej księgi mówiący o nadziej, która przenika poza zasłonę, gdzie Jezus jako poprzednik wszedt ( $\epsilon \mathfrak{\imath}\lceil\hat{\eta} \lambda \theta \in \nu)$ za nas, stawszy się arcykapłanem na wieki na wzór Melchizedeka (Hbr 6,20). Z jednej strony Chrystus ukazany jest jako ten, który wchodzi poza zasłonę, stając się nowym - wiecznym arcykapłanem, a z drugiej jako ten, który sam staje się pośrednikiem łączącym ludzi z Bogiem. Jezus jest zatem tym, który zapoczątkował nową drogę, nową jakość życia, stał się dla wierzących „drogowskazem do nieba, wzorem nowego «sposobu postępowania»" 46 . Istotne jest to, że Chrystus nie tylko sam wszedł do niebiańskiej świątyni, ale zapewnił innym możliwość wejścia: Mamy więc, bracia, pewność, iż wejdziemy ( $\epsilon$ løodov) do Miejsca Świętego przez krew Jezusa $(\mathrm{Hbr} 10,19)^{47}$. Zatem droga, którą On zapoczątkował jest otwarta dla wszystkich, staje się prawdziwą óoós dla całego Kościoła.

\subsection{Wejście do odpoczynku Pana (Hbr 3,1-4,11)}

Warto zwrócić uwagę na jeszcze inny fragment Listu do Hebrajczyków, w którym mowa jest o przejściu Jezusa do nowej rzeczywistości i zapoczątkowaniu drogi otwartej dla wszystkich wierzących. W czwartym rozdziale autor nawiązuje do istniejącej obietnicy wejścia do odpoczynku (por. Hbr 4,1-11). Jako pierwsi otrzymali ją Izraelici przebywający na pustyni, nie mogli jednak znaleźć

\footnotetext{
44 A. Tronina, Do Hebrajczyków, s. 131. 
„odpoczynku Ziemi Obiecanej”, ponieważ zgrzeszyli i nie uwierzyli Bogu (por. Lb 14,21-23). Tekstem poprzedzającym fragment Hbr 4,1-11 jest cytat z Księgi Psalmów: Rozgniewałem się przeto na to pokolenie i powiedziałem: Zawsze bła-

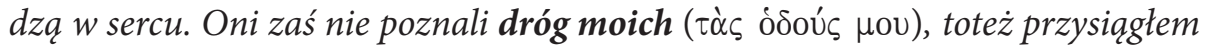
w swym gniewie: Nie wejda ( $\epsilon i \sigma \in \lambda \in \cup ́ \sigma o \nu \tau \alpha \iota)$ do mego odpoczynku (Hbr 3,10-11, por. Ps 95,10-11). Wyraz óđós, mimo że pochodzi z Psalmu 95, wpisuje się jednak w kontekst rozdziałów 3 i 4. Bóg nie pozwolił wejść Izraelitom do Ziemi Obiecanej, bo oni nie poznali Jego dróg. Jednak dana przez Niego obietnica zachowuje na zawsze swoją moc: Lękajmy się przeto, gdy jeszcze trwa obietnica wejścia do Jego odpoczynku, aby ktoś $z$ was nie mniemał, iż jest jej pozbawiony $(\text { Hbr } 4,1)^{48}$. Autor Hebrajczyków pisze dalej, że Jozue, który miał po śmierci Mojżesza wejść z Narodem Wybranym do Ziemi Obiecanej, nie wprowadził ich tak naprawdę do odpoczynku, stąd musiał pozostać w Prawie odpoczynek szabatu, który był antycypacją czekającego „odpoczynku błogosławieństwa Bożego" ${ }^{49}$ w niebie (por. Hbr 4,8-9). Dopiero Jezus, którego w tym fragmencie przeciwstawiono Mojżeszowi, jako Tego, który godzien jest większej czci (Hbr 3,3), jest jednocześnie Tym, który może wprowadzić do nowego, prawdziwego odpoczynku. Jest to dar Boga, nie można na niego zasłużyć ludzkimi roszczeniami, lecz jedynie wiarą w Chrystusa - jedyną drogę naszego zbawienia ${ }^{50}$. Stąd apel autora listu: Śpieszmy się więc wejść ( $\in \dot{\imath} \sigma \in \lambda \theta \in \hat{\imath} \nu$ ) do owego odpoczynku, aby nikt nie poszedł za tym samym przykładem nieposłuszeństwa ${ }^{51}$ (Hbr 4,11).

Jak widać, List do Hebrajczyków przesiąknięty jest terminologią związaną z ruchem, wstępowaniem i pielgrzymowaniem, użyto także kluczowego dla świętego Łukasza sformułowania óoóc. Wykorzystanie przez autora tej księgi tak specyficznych wyrażeń, pozwala odkryć istotną cechę jego teologii. W motyw „drogi” wpisał on popaschalny obraz nowego Świętego Miasta, Królestwa, do którego wprowadza wierzących Zmartwychwstały Chrystus.

\section{Podsumowanie}

Święty Łukasz natchniony przez Boga stworzył piękne dzieło, opierając się na znanej mu tradycji (na tekście spisanym i przekazanym ustnie), chciał nadać mu własny, specyficzny charakter. Używając doskonałej greki, przekazał pełen dynamizmu obraz Jezusa i założonej przez Niego wspólnoty.

\footnotetext{
48 Por. Biblia Jerozolimska, s. 1689, przypis 4,1.

49 Por. ibidem.

50 Por. A. Tronina, Do Hebrajczyków, s. 75; S. Łach, List do Hebrajczyków, s. 161.

51 Mowa o nieposłuszeństwie Izraelitów (por. Lb 14,21-23).
} 
Łukasz nazywany jest redaktorem „drogi Pana”, gdyż uczynił on ją motywem całego swojego dzieła. Warto podkreślić, że jest on obecny także w Liście do Hebrajczyków, co może posłużyć jako jeden z argumentów za Łukaszowym autorstwem tej księgi. Motyw drogi jest fundamentem, na którym święty Łukasz zbudował swoje dzieła. Łączy je niewątpliwie, nie tylko użycie identycznych słów, lecz także podobna struktura. Opus Lucanum to opis pielgrzymki Syna Bożego, który stając się człowiekiem, zaprosił wszystkich ludzi do pójścia Jego drogą, aby poprzez ziemskie miasta dojść w końcu do tego najpiękniejszego, do Nowego Jeruzalem.

\section{Bibliografia}

Buchanan G.W., Miejsce Święte, w: Encyklopedia biblijna, P.J. Achtemeier (red.), Warszawa ${ }^{2} 1999$, s. 759.

Darrieutort A., Droga, w: Słownik teologii biblijnej, X. Léon-Dufour (red.), Poznań 1994, s. 220-222.

Dąbrowski E., Studia Biblijne, Poznań ${ }^{2} 1952$.

Euzebiusz z Cezarei, Historia Kościelna. O męczennikach palestyńskich (tłum. A. Lisiecki), Poznań 1924.

Frankowski J., Problem autorstwa Listu do Hebrajczyków i etapy egzegezy katolickiej $w$ dobie wspótczesnej, SThV 7(1969), s. 3-33.

Gnilka J., Teologia Nowego Testamentu, Kraków 2002.

Jelonek T., Postać Mojżesza w Nowym Testamencie, RBL 26(1973), s. 107-110.

Jelonek T., Streszczenie dzieł Łukaszowych w Liście do Hebrajczyków, AnCr 13(1981), s. $143-151$.

Jelonek T., Typologia Mojżesz - Chrystus w dziełach św. Łukasza, AnCra 8(1976), s. 111-124.

Kotecki D., „Droga” jako element jedności literacko-teologicznej Ewangelii Łukasza i Dziejów Apostolskich, BePTh 1(2008), s. 55-76.

Kozyra J., List świętego Jakuba, Częstochowa 2011.

Łach S., List do Hebrajczyków, Poznań 1959.

Paciorek A., Paweł Apostot - pisma, cz. II, Tarnów 2004.

Popowski R. i Wojciechowski M., Grecko-polski Nowy Testament. Wydanie interlinearne z kodami gramatycznymi, Warszawa 1997.

Popowski R., Wielki stownik grecko-polski Nowego Testamentu, Warszawa 1997.

Rosik M., Pierwszy List do Koryntian, Częstochowa 2009.

Sobór Watykański II, Konstytucja o Liturgii Świętej, w: Sobór Watykański II. Konstytucje, Dekrety, Deklaracje, Poznań 2002, s. 48-78.

Thompson J.W., List do Hebrajczyków, w: Encyklopedia biblijna, P.J. Achtemeier (red.), Warszawa ${ }^{2} 1999$, s. 681-682.

Tronina A., Do Hebrajczyków. Słowo zachęty na dni ostatnie, Częstochowa 1998. 